\title{
Cost Of Debt And Dividend Policy: Evidence From The MENA Region
}

Omar Farooq, Ph.D., ESSCA Ecolde de Management, France

Imad Jabbouri, Ph.D., Al Akhawayn University in Ifrane, Morocco

\begin{abstract}
How does dividend policy effect cost of debt in emerging markets? Does it increase the perceived conflict of interests between creditors and shareholders or vice versa? This paper seeks to answer these questions by documenting the relationship between dividend payout ratios and cost of debt in emerging markets. Using a dataset from the MENA region, we document a significantly negative relationship between dividend payout ratios and cost of debt during the period between 2005 and 2011. We argue that high dividend payouts reduce information asymmetries. Consequently, creditors demand lower return for providing their capital to firms. We also show that the negative relationship between dividend payout ratios and cost of debt are more pronounced in firms with higher information asymmetries. It indicates that value relevance of high dividend payout ratios is more in firms that have higher information asymmetries. These firms have scarcity of information. Therefore, whenever information environment improves, it is highly valued by creditors.
\end{abstract}

Keywords: MENA Countries; Cost of Debt; Dividend Policy; Emerging Markets

\section{INTRODUCTION}

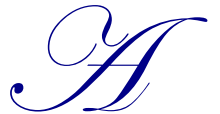

$\mathrm{n}$ important concern faced by every investor in emerging markets is to accurately gauge the financial conditions of firms they are planning to invest in. Financial conditions of firms determine the associated risks and, therefore the required rate of returns. Investors demand lower returns for investing in firms with lower risk. However, it is not always easy to obtain true information about firms in emerging markets. Prior literature associates emerging markets with inadequate disclosure and governance mechanisms - both at the firm-level and the country-level. Claessens and Fan (2003), for instance, document that firm-level governance mechanisms are weak in emerging markets. While, Khwaja and Mian (2006) show that country-level governance structures are relatively ineffective in Pakistan - an emerging market. These and numerous other studies argue that weak enforcement of investor protection laws, presence of family control, and lax implementation of anti-director rights contribute to ineffectiveness of disclosure and governance mechanisms in emerging markets. An important implication of ineffective disclosure and governance mechanisms is that the culture of information disclosure could not evolve in these markets. Leuz et al. (2003) document that managers and insiders do not disclose true information about their firms in emerging markets. This leaves investors with an impossible task of assessing true value of firms. As a consequence, it becomes hard for them to make any informed investment decision.

This paper documents how creditors - one of the main providers of capital - can resolve information asymmetries in emerging markets. We argue that dividend policies adopted by firms have incremental information, in excess of what is present in the financial statements, for investors regarding the financial conditions of firms. Prior literature argues that high dividend payouts alleviate agency conflicts through the reduction of free cash flow available with managers (Grossman and Hart, 1980). In a related study, Jensen (1986) concludes that high dividend payouts lessen agency problems by reducing free cash flows that can be expensed on unprofitable projects. This strand of literature argues that paying high dividends reflects managements' good faith and signals low agency problems. La Porta et al. (2000) formalize the above findings in a theory known as the substitute model. The substitute model argues that dividends can substitute for the monitoring roles of the stakeholders. It posits that firms operating in relatively poor governance environments make dividend payments to establish a reputation for acting in 
the best interest of minority shareholders. High dividend payments signal to the market that there is less cash at the expense of management to expropriate. Consequently, high dividend payments are associated with lower information asymmetries. This paper argues that lower information asymmetries associated with firms paying high dividends should translate into lower cost of debt. Our arguments are consistent with Bhojraj and Senpgupta (2003) who document a positive correlation between disclosure and bond ratings and a negative relation between disclosure and bond yields. They argue that superior disclosure and governance mechanisms reduce default risk by mitigating agency costs. In another related study, Mathur et al. (2013) show that debt holders view dividends as a positive signal about firm's prospect. They argue that positive signal emanating through dividend payout results in lower bond yields. ${ }^{1}$

In this paper, we extend the above findings by documenting the impact of dividend payout ratios on cost of debt in the MENA region (Bahrain, Egypt, Jordan, Kuwait, Morocco, Oman, Qatar, Saudi Arabia, Tunisia, and United Arab Emirates) during the region between 2005 and 2011. Our results show that cost of debt is negatively related to dividend payout ratios. Our results are consistent with previous literature that associates high payout ratios with lower information asymmetries (La Porta et al., 2000). Lower information asymmetries reduce the risk faced by creditors. We argue that lower risk faced by creditors translates into lower required return (Blom and Schauten, 2008; Farooq and Derrabi, 2012). Interestingly, we also show that our results are more pronounced in firms with higher information asymmetries. We argue that value relevance of dividend payout ratios is greater for firms that have higher information asymmetries. These firms have scarcity of information. Therefore, whenever information disclosure improves, it is highly valued by investors. ${ }^{2}$ Our arguments are consistent with Lang et al. (2004) who document a positive valuation effect of mechanisms that improve information asymmetries in countries with poor information environment. They argue that countries with high information asymmetries have dearth of information. Therefore, whenever information disclosure improves, it is highly valued by investors.

The remainder of the paper is structured as follows: Section 2 summarizes the data and Section 3 presents assessment of our hypothesis. Section 4 documents robustness of our results and the paper ends with Section 5 where we present our conclusions.

\section{DATA}

This paper documents the relationship between cost of debt and dividend policy in the MENA region. Our sample consists of nonfinancial firms listed at the stock exchanges of Bahrain, Egypt, Jordan, Kuwait, Morocco, Oman, Qatar, Saudi Arabia, Tunisia, and United Arab Emirates. Our sample covers the period between 2005 and 2011. We will, briefly, describe the data in following sections.

\section{Cost of Debt}

Cost of debt is calculated as the interest expense for the financial year divided by total debt during the same year. ${ }^{3}$ The data for interest expense and total debt are obtained from the Worldscope. Table 1 documents the descriptive statistics for the cost of debt during our sample period. The result in Panel A shows that cost of debt is the highest in Egypt and Tunisia, while it is the lowest in Saudi Arabia and Qatar. Our results in Panel B show that firms belonging to Oil and Gas sector are able to raise debt at the most competitive rates. Panel C indicate relative

\footnotetext{
${ }^{1}$ Given that information asymmetries are associated with corporate governance mechanisms, prior literature has extensively related various proxies of corporate governance with the cost of debt. For instance, Boubakri and Ghouma (2010) relate ownership structure with cost of debt, Ortiz-Molina (2006) relate managerial incentives with cost of debt, and Liu and Jiraporn (2010) CEO power with cost of debt.

${ }^{2}$ We would like to mention here that we are aware of the arguments that relate higher dividend payouts with higher cost of debt. These arguments revolve around the conflicts of interests between creditors and shareholders. These arguments state that high dividends can increase the agency conflicts between creditors and shareholders. Dividends reduce the cash available to meet firm's predetermined obligations including principle and interest payments on debt. Given that there is adverse market reaction associated with dividend reductions, many firms would rather borrow to avoid cutting dividends. The additional leverage increases firm's risk with a consequent increase in the cost of debt. To the extent that creditors view dividends negatively, they demand a higher rate of return from firms with large dividend payouts. This yields a positive relation between dividend payouts and cost of debt.

${ }^{3}$ The preliminary statistics indicate that the outcome provides abnormal values, and thus may introduce noise in the measurement of the effective cost of debt for a firm. Therefore, following Pittman and Fortin (2004), we trim the data to address extreme observations, and winsorised the allowed spread at the 5 th and $95^{\text {th }}$ percentiles of the initial pooled distribution.
} 
homogeneity in the cost of debt across the years. We report, approximately, same cost of debt across our sample period.

Table 1. Descriptive statistics for cost of debt

\begin{tabular}{|c|c|c|}
\hline Country & Mean & Median \\
\hline Bahrain & 0.0617 & 0.0561 \\
\hline Egypt & 0.0827 & 0.0797 \\
\hline Jordan & 0.0787 & 0.0736 \\
\hline Kuwait & 0.0649 & 0.0579 \\
\hline Morocco & 0.0618 & 0.0534 \\
\hline Oman & 0.0581 & 0.0526 \\
\hline Qatar & 0.0429 & 0.0359 \\
\hline Saudi Arabia & 0.0402 & 0.0329 \\
\hline Tunisia & 0.0823 & 0.0684 \\
\hline United Arab Emirates & 0.0531 & 0.0474 \\
\hline \multicolumn{3}{|c|}{ Panel B: Cost of debt within each industry } \\
\hline Industry & Mean & Median \\
\hline Oil and Gas & 0.0491 & 0.0457 \\
\hline Basic Materials & 0.0616 & 0.0575 \\
\hline Industrials & 0.0636 & 0.0554 \\
\hline Consumer Goods & 0.0716 & 0.0627 \\
\hline Consumer Services & 0.0647 & 0.0571 \\
\hline Telecommunications & 0.0709 & 0.0641 \\
\hline Technology & 0.0607 & 0.0565 \\
\hline Utilities & 0.0681 & 0.0551 \\
\hline Healthcare & 0.0703 & 0.0557 \\
\hline \multicolumn{3}{|c|}{ Panel C: Cost of debt during each year } \\
\hline Year & Mean & Median \\
\hline 2005 & 0.0667 & 0.0554 \\
\hline 2006 & 0.0688 & 0.0604 \\
\hline 2007 & 0.0693 & 0.0615 \\
\hline 2008 & 0.0673 & 0.0587 \\
\hline 2009 & 0.0684 & 0.0577 \\
\hline 2010 & 0.0611 & 0.0534 \\
\hline 2011 & 0.0568 & 0.0517 \\
\hline
\end{tabular}

\section{Dividend Policy}

In this study, we consider dividend payout ratio as a proxy for dividend policy. The descriptive statistics for dividend policy are presented in Table 2. Panel A reports relatively low level of payout ratios in the sample countries. None of the countries, except Morocco, have payout ratio exceeding 50\%. This observation is consistent with the findings of previous studies that document relatively lower level of payout ratios in emerging markets. Panel B and Panel C support our earlier observation of low payout ratios. We report low payout ratios across all industries and across all years in our sample, suggesting homogeneity in dividend policies across industries and years. Our result in Panel $\mathrm{C}$ also show that increase in payout ratios in the later part of our sample. Given that payout ratios are proxy of governance mechanisms, our results may indicate the improvement in governance mechanisms in the region. 
Table 2. Descriptive statistics for dividend policy

Panel A: Dividend policy within each country

\begin{tabular}{|c|c|c|}
\hline Country & Mean & Median \\
\hline Bahrain & 48.3147 & 47.4800 \\
\hline Egypt & 44.2284 & 48.7800 \\
\hline Jordan & 45.4483 & 54.0250 \\
\hline Kuwait & 29.5610 & 21.3400 \\
\hline Morocco & 51.8411 & 56.4700 \\
\hline Oman & 41.2477 & 44.2000 \\
\hline Qatar & 39.7201 & 41.4100 \\
\hline Saudi Arabia & 33.7605 & 33.0600 \\
\hline Tunisia & 36.8356 & 41.0000 \\
\hline United Arab Emirates & 30.5116 & 25.8400 \\
\hline
\end{tabular}

Panel B: Dividend policy within each industry

\begin{tabular}{lcc}
\hline \multicolumn{1}{c}{ Industry } & Mean & Median \\
\hline Oil and Gas & 38.3303 & 40.6700 \\
Basic Materials & 38.4881 & 41.9250 \\
Industrials & 39.9966 & 43.2650 \\
Consumer Goods & 36.6310 & 39.1200 \\
Consumer Services & 38.5508 & 38.0500 \\
Telecommunications & 42.5294 & 46.9250 \\
Technology & 47.8950 & 50.7800 \\
Utilities & 53.5380 & 55.0500 \\
Healthcare & 39.9127 & 48.8000 \\
\hline & & \\
Panel C: Dividend policy during each year & & Median \\
\hline 2005 & Mean & 32.8650 \\
2006 & 34.5838 & 42.5400 \\
2007 & 38.8504 & 39.065 \\
2008 & 38.8078 & 38.8900 \\
2009 & 37.5717 & 40.5400 \\
2010 & 37.7137 & 44.8300 \\
\hline
\end{tabular}

\section{Control Variables}

This paper uses log of total assets (SIZE), total debt to total asset ratio (LEVERAGE), earnings per share (EPS), growth in assets (GROWTH), and interest coverage ratio (COVRATIO) as control variables. Descriptive statistics for control variables are provided in Table 3. An interesting observation from Table 3, Panel A, is low median EPS. It indicates that almost half of the firms in the MENA region were not very profitable in our sample period. Table 3, Panel B, shows low levels of correlations between variables. It indicates that we can include all of the variables together in our regression equation. 
Table 3. Descriptive statistics for control variables

Panel A: Variables

\begin{tabular}{lcc}
\hline & Mean & Median \\
\hline SIZE & 11.9651 & 11.8895 \\
LEVERAGE & 19.1314 & 13.8200 \\
EPS & 4.4892 & 0.1300 \\
GROWTH & 11.8737 & 6.75500 \\
COVRATIO & 18.6321 & 4.7300 \\
\hline
\end{tabular}

\begin{tabular}{|c|c|c|c|c|c|}
\hline & SIZE & LEVERAGE & EPS & GROWTH & COVRATIO \\
\hline SIZE & 1.0000 & & & & \\
\hline LEVERAGE & 0.1180 & 1.0000 & & & \\
\hline EPS & 0.2382 & -0.0060 & 1.0000 & & \\
\hline GROWTH & 0.1499 & 0.0614 & 0.0032 & 1.0000 & \\
\hline COVRATIO & 0.0739 & -0.2608 & 0.1028 & 0.0257 & 1.0000 \\
\hline
\end{tabular}

\section{Methodology}

The paper documents the effect of payout ratio on cost of debt in the MENA region. More In order to test this hypothesis, we estimate a panel regression with cost of debt $(\mathrm{CoD})$ as a dependent variable and dividend payout ratio $(\mathrm{PoR})$ as an independent variable. Furthermore, mindful of the effects that firm-specific characteristics may have on cost of debt, we also add number of firm-specific variables in our regression equation as control variables. These variables are SIZE, LEVERAGE, EPS, GROWTH, and COVRATIO. To control for unobserved heterogeneity, we also include dummy variables representing firm-specific fixed effects (FDUM). It is important to mention here that we use panel data regression with fixed effects for our analysis. Hausman test was used to decide between fixed effect and random effects. Our basic regression takes the following form.

$$
\begin{aligned}
& \mathrm{CoD}=\alpha+\beta_{1}(\mathrm{PoR}) \\
& +\beta_{2}(\mathrm{SIZE})+\beta_{3}(\text { LEVERAGE })+\beta_{4}(\mathrm{EPS}) \\
& +\beta_{5}(\mathrm{GROWTH})+\beta_{6}(\text { COVRATIO })+\sum_{\mathrm{Fxd}} \beta^{\mathrm{Fxd}}(\mathrm{FDUM})+\varepsilon
\end{aligned}
$$

The results of our analysis are reported in Table 4. Our result shows that increase in dividend payout ratio causes cost of debt to go down by 0.0080 units. We report significant and negative coefficient of PoR. We argue that increase in dividend payout ratios are used by firms as a signal to tell investors that firms are governed properly. Good governance should result in lowering information asymmetries, thereby reducing the cost of debt. Furthermore, high payout ratios may also indicate lower level of agency problems within the firm by signaling to the market that no excess cash is available to expropriate (Easterbrook, 1984). This will also result in lowering the cost of debt.

Table 4. Relationship between dividend policy and cost of debt

\begin{tabular}{lc}
\hline Variables & Equation (1) \\
\hline PoR & $-0.0080^{* *}$ \\
GROWTH & $-0.0204^{* * *}$ \\
SIZE & 0.4399 \\
LEVERAGE & $-0.1334^{* * * *}$ \\
EPS & $-0.0170^{*}$ \\
COVRATIO & $-0.0305^{* * *}$ \\
Fixed Effects & Yes \\
No. of observations & 1437 \\
No. of groups & 407 \\
F-value & 12.12 \\
$\mathrm{R}^{2}$ within & 0.2166 \\
\hline
\end{tabular}

Note: The results significant at $10 \%$ significance level are followed by $*$, at $5 \%$ significance level by $* *$, and at $1 \%$ a significance level by***. 


\section{ROBUSTNESS OF RESULTS}

\section{Effect of Legal Traditions on the Relationship Between Dividend Policy and Cost of Debt}

In this section, we divide our sample into two groups - one group with firms headquartered in the civil law countries and the other group with firms headquartered in the common law countries. We re-estimate Equation (1) for both groups. Our results are reported in Table 5. Our results show that our earlier findings hold only in the civil law countries. We report significantly negative coefficient of PoR in the civil law countries and insignificant coefficient of PoR in the common law countries. These findings are interesting as well as intuitive. Given that firms in the civil law countries experience higher information asymmetries, conventional wisdom would suggest that value relevance of dividend policy should be higher in the civil law countries. Our arguments are consistent with Lang et al. (2004) who document a positive valuation effect of mechanisms that improve information asymmetries in countries with poor information environment. They argue that countries with high information asymmetries have scarcity of information. Therefore, whenever information disclosure improves, it is highly valued by investors.

Table 5. Effect of legal traditions on the relationship between dividend policy and cost of debt

\begin{tabular}{lcc}
\hline Variables & Common Law & Civil Law \\
\hline PoR & -0.0034 & $-0.0092^{* *}$ \\
GROWTH & $-0.0293^{* * *}$ & $-0.0197^{* * *}$ \\
SIZE & 0.8484 & 0.4252 \\
LEVERAGE & $-0.1170^{* * *}$ & $-0.1379^{* * *}$ \\
EPS & -0.0644 & $-0.0163^{*}$ \\
COVRATIO & $-0.0183^{* * *}$ & $-0.0356^{* * *}$ \\
Fixed Effects & Yes & Yes \\
No. of observations & 346 & 1091 \\
No. of groups & 99 & 308 \\
F-value & 5.71 & 9.29 \\
$\mathrm{R}^{2}$ within & 0.2482 & 0.2206 \\
\hline
\end{tabular}

Note: The results significant at $10 \%$ significance level are followed by $*$, at $5 \%$ significance level by $* *$, and at $1 \%$ a significance level by***.

\section{Effect of Growth Opportunities on the Relationship Between Dividend Policy and Cost of Debt}

In this section, we divide our sample into two groups - one group with above median growth of entire sample and the other group with below median growth of entire sample. Main motivation behind dividing our sample into low growth and high growth firms is our assumption that high growth firms have higher information symmetries. Existing studies argue that the asymmetric information problem is more severe for firms with significant growth opportunities (Smith and Watts, 1992). We re-estimate Equation (1) for both groups. We present our results in Table 6. Our results show that our earlier findings hold only in high growth firms. We report significantly negative coefficient of PoR for high growth firms and insignificant coefficient of PoR for low growth firms. As was mentioned earlier, we argue that high information asymmetries embedded in high growth firms make payout ratios more value relevant in these firms relative to low growth firms.

Table 6. Effect of growth on the relationship between dividend policy and cost of debt

\begin{tabular}{lcc}
\hline Variables & High Growth & Low Growth \\
\hline PoR & $-0.0091^{*}$ & -0.0084 \\
GROWTH & $-0.0191^{* * *}$ & -0.0216 \\
SIZE & 0.1444 & 1.0505 \\
LEVERAGE & $-0.1283^{* * *}$ & $-0.1290^{* * *}$ \\
EPS & -0.0094 & -0.0278 \\
COVRATIO & $-0.0273^{* * *}$ & $-0.0325^{* * *}$ \\
Fixed Effects & Yes & Yes \\
No. of observations & 805 & 632 \\
No. of groups & 337 & 315 \\
F-value & 6.07 & 5.41 \\
$\mathrm{R}^{2}$ within & 0.1982 & 0.2645 \\
\hline
\end{tabular}

Note: The results significant at $10 \%$ significance level are followed by $*$, at $5 \%$ significance level by $* *$, and at $1 \%$ a significance level by***. 


\section{CONCLUSION}

This paper explores the relationship between dividend payout ratios and cost of debt in the MENA region during the period between 2005 and 2011. Our results show a significantly negative relationship between cost of debt and dividend payout ratios. We argue that high payout ratios alleviate agency conflicts and lower information asymmetries. Lower information asymmetries reduce the risk faced by creditors. As a result, they require lower return for providing capital to firms with high dividend payout ratios. We also show that our results are more pronounced in firms with higher information asymmetries. This indicates that value relevance of dividend payout ratios is higher in firms that have higher information asymmetries. These firms have scarcity of information. Therefore, whenever information environment improves, it is highly valued by creditors.

\section{AUTHORS' INFORMATION}

Omar Farooq is an Associate Professor of Finance at the ESSCA Ecole de Management, France. He holds a PhD from Hanken School of Economics, Finland. His areas of expertise are in Corporate Governance and Corporate Finance. E-mail: omar.farooq.awan@gmail.com (Corresponding author)

Imad Jabbouri, School of Business Administration, Al Akhawayn University in Ifrane, Morocco

\section{REFERENCES}

Bhojraj, S., Senpgupta, P., (2003). Effect of Corporate Governance on Bond Ratings and Yields: The Role of Institutional Investors and Outside Directors. Journal of Business, 76(3), 455-476.

Blom, J. and Schauten, M. B. J., (2008). Corporate Governance and the Cost of Debt. In: Soares, J.O., Pina, J. and M. Catalao-Lopes, New Developments in Financial Modeling, Cambridge Scholars Publishing, pp. 116145 .

Boubakri, N. and Ghouma, H., (2010). Managerial Opportunism, Cost of Debt Financing, and Regulation Changes: Evidence from the Sarbanes-Oxley Act Adoption. Working Paper, HEC Montreal, Canada.

Claessens, S. and Fan, J. P. H., (2003). Corporate Governance in Asia: A Survey. International Review of Finance, 3(2), pp. 71-103.

Easterbrook, F. H., (1984). Two Agency-Cost Explanations of Dividends. American Economic Review, 74(4), pp. 650-659.

Farooq, O. and Derrabi, M., (2012). Effect of Corporate Governance Mechanisms on the Relationship between Legal Origins and Cost of Debt: Evidence from the Middle East and North Africa (MENA) Region. African Journal of Business Management, 6(7), pp. 2706-2715.

Grossman, S. and Hart, O., (1980). Disclosure Laws and Take-over Bids. Journal of Finance, 35(2), pp. 323-334.

Jensen, M. C., (1986). Agency Costs of Free Cash Flow, Corporate Finance, and Takeovers. American Economic Review, 76(2), pp. 323-329.

Khwaja, A. I. and Mian, A., (2006). Unchecked Intermediaries: Price Manipulation in an Emerging Stock Market. Journal of Financial Economics, 78(1), pp. 203-241.

La Porta, R., Lopez-de-Silanes, F., Shleifer, A., and Vishny, R., (2000). Agency Problems and Dividend Policies around the World. Journal of Finance, 55(1), pp. 1-33.

Lang, M. H., Lins, K. V., and Miller, D. P., (2004). Concentrated Control, Analyst Following, and Valuation: Do Analysts Matter Most When Investors are Protected Least? Journal of Accounting Research, 42(3), pp. 589-623.

Leuz, C., Nanda, D., and Wysocki, P. D., (2003). Earnings Management and Investor Protection: An International Comparison. Journal of Financial Economics, 69(3), pp. 505-527.

Liu, Y. and Jiraporn, P., (2010). The Effect of CEO Power on Bond Ratings and Yields. Journal of Empirical Finance, 17(4), pp. 744-762.

Mathur, I., Singh, M., Nejadmalayeri, A., and Jiraporn, P., (2013). How do Bond Investors Perceive Dividend Payouts? Research in International Business and Finance, 27(1), pp. 92-105.

Ortiz-Molina, H., (2006). Top-management Incentives and the Pricing of Corporate Public Debt. Journal of Financial and Quantitative Analysis, 41(2), pp. 317-340. 
Pittman, J. A. and Fortin, S., (2004). Auditor Choice and the Cost of Debt Capital for Newly Public Firms. Journal of Accounting and Economics, 37(1), pp. 113-136.

Smith, C. W. and Watts, R. L., (1992). The Investment Opportunity Set and Corporate Financing, Dividend, and Compensation Policies. Journal of Financial Economics, 32(3), pp. 263-292. 